\title{
Penerapan Keselamatan dan Kesehatan Kerja (K3) pada Atraksi Adventure Tourism di Kawasan Air Terjun Aling-Aling Sambangan
}

Rut Wiratami a, 1, Gde Indra Bhaskara a, 2

1irut_mekeprut@yahoo.co.id, 2gbhaskara@unud.ac.id

a Program Studi S1 Destinasi Pariwisata, Fakultas Pariwisata,Universitas Udayana, Jl. Dr. R. Goris, Denpasar, Bali 80232 Indonesia

\section{Abstract}

Tourist safety is an important aspect in tourism activities and must have serious attention from the manager of a tourism destination. It is also one of tourist satisfaction over the service which further will imposes image of the destination around the world. Sambangan tourism village is one of the tourist destinations in North Bali which is currently popular to domestic and foreign tourists. There are two unique attractions become flagship attractions that are sliding and jumping. Along with the development of an increasing tourist visits since last few years, problems began appear. An accident even cause the loss of life and one of them is a local guide who made a living in that area. Therefore, this research is considered necessary and important in order to find out how the application of safety and health of work have been done so far. Data obtained through library studies, participatory observation and interviews with the determined informants. This research found that the safety and health aspects of work in Sambangan tourism village are still simple due to the limitations of funding and a lack of understanding in the health aspects so that the implementation of health and safety of work is done based on understanding. Therefore, in the future a further research is needed related to the health aspects of a medical, increasing of security aspects in the location of tourists attraction and also the attention and support from the government especially tourism department.

Keywords : Safety and Healthy, Adventure Tourism, Attraction, Waterfall.

\section{PENDAHULUAN}

Kegiatan pariwisata bertujuan untuk memperoleh profit/keuntungan ekonomi bagi pengelola suatu destinasi khususnya masyarakat lokal sebagai host dan memberikan kepuasan kepada wisatawan sebagai guest atas produk yang dijual. Dua hal ini hendaknya membentuk sebuah integrasi yang dapat menguntungkan kedua belah pihak. Kepuasan tersebut meliputi profesionalitas kinerja dan keramahtamahan guide saat melayani wisatawan, fasilitas pendukung pariwisata yang memadai, dan hal terpenting adalah keselamatan dan kesehatan wisatawan atau sering disingkat dengan K3.

"Keselamatan kerja dalam suatu tempat mencangkup berbagai aspek yang berkaitan dengan kondisi dan keselamatan sarana dan prasarana produksi, manusia dan cara kerja" (Undang-Undang No. 1 tahun 1970). Jika diimplementasikan dalam konteks pariwisata, keselamatan dan kesehatan kerja yang dimaksudkan dalam penelitian ini ditekankan pada aspek keselamatan kerja. Keselamatan kerja tersebut meliputi keselamatan sarana dan prasarana atraksi wisata/kondisi lingkungan kerja, keselamatan pemandu wisata dan wisatawan, serta keselamatan pada cara kerja/prosedur saat melakukan atraksi wisata. Apabila ketiga komponen keselamatan kerja ini dapat dipenuhi maka dapat menekan sekecil mungkin risiko-risiko kecelakaan yang tidak diinginkan. Secara umum, aspek keselamatan termasuk di dalamnya keberadaan infratruktur, fasilitas, sarana dan personel penyelamat, di banyak daya tarik wisata masih terabaikan. Pengelolaan daya tarik wisata semestinya mengintegrasikan infratruktur dan perlengkapan keselamatan di dalamnya sejak awal. Kurangnya perhatian pemerintah dan masyarakat terhadap keselamatan publik di tempat-tempat pariwisata menyebabkan kurangnya pengendalian terhadap risiko yang ada. Tidak tersedianya sarana keselamatan yang sesuai standar merupakan salah satu penyebab terjadinya kecelakaan di kawasan wisata. Bahkan tak sedikit daya tarik wisata yang sama sekali tidak memiliki fasilitas penyelamatan tersebut meski pengunjung cukup ramai terutama wisatawan nusantara. Kita tidak bisa menduga bahwa musibah bisa terjadi setiap saat. Melalui peningkatan aspek keselamatan di lokasi wisata, setidaknya dapat menekan risiko musibah menjadi sekecil mungkin. 
Hal tersebutlah yang menjadi alasan penelitian tentang aspek keselamatan di kawasan Air Terjun Aling-Aling Desa Sambangan ini dilakukan, dengan harapan ke depannya segala aktivitas pariwisata yang berlangsung di dalamnya dapat berjalan dengan baik, aman dan nyaman baik bagi pengelola terlebih bagi wisatawan yang berkunjung sehingga citra daya tarik wisata tetap terjaga baik pula.

\section{TINJAUAN PUSTAKA}

Penelitian sebelumnya yang dijadikan referensi dalam penelitian ini ada dua yang didasarkan pada kesamaan lokus dan topik. Penelitian yang dilakukan oleh Anak Agung Gde Raka Dalem tahun 2009 tentang Potensi, Prospek dan Penyusunan Program dalam Pengembangan Ekowisata di Desa Sambangan, Kecamatan Sukasada, Kabupaten Buleleng, Bali. Dengan persamaan lokus, hasil penelitiannya disebutkan bahwa Desa Sambangan memiliki potensi dalam pengembangan ekowisata, di samping agrowisata dan wisata spiritual. Paket wisata yang bisa dijual dan sudah mulai digarap adalah trekking dan meditasi serta camping. Trekking ini diantaranya memanfaatkan kawasan hutan desa yang di dalamnya terdapat beberapa air terjun dan juga memanfaatkan lokasi pertanian sehingga berkaitan dengan kegiatan ekowisata. Keterbatasan permodalan dan rendahnya kualitas SDM merupakan kendala dalam pengembangan ekowisata di desa ini. Namun kendala ini masih bisa diatasi jika berbagai pihak terkait (stakeholder) mau bekerjasama di dalam pengembangan ekowisata di wilayah ini.

Adapun paket trekking yang sudah dirancang dan dikemas sejak awal program pengembangan ekowisata di Desa Sambangan sampai saat ini tetap dijual kepada wisatawan bahkan menjadi daya tarik dan atraksi unggulan di desa ini. Di dalam paket short trekking tersebut terdapat atraksi sliding dan jumping yang menjadi objek penelitian terkait dengan aspek keselamatan dan kesehatan kerja pada atraksi wisata dan pelaku atraksi yakni Guide dan wisatawan.

Selanjutnya penelitian dengan kesamaan topik yaitu penerapan K3 di Benoa Tirta Harum
Dive and Watersport oleh Agastya, 2014. Dalam penelitiannya disebutkan bahwa pihak pengelola watersport sudah mempunyai SOP (Standard Operational Procedure) yang patut dan harus dilaksanakan oleh seluruh karyawan saat dan selama berlangsungnya aktivitas watersport. Adapun kendala yang dihadapi oleh pihak pengelola adalah kurangnya kemampuan karyawan dalam penguasaan bahasa asing dan kondisi peralatan watersport yang jarang dirawat.

Dari hasil penelitian tersebut, ada beberapa hal penting yang dapat dijadikan tolak ukur dalam penelitian selanjutnya yaitu pentingnya peran karyawan/guide dalam menguasai prosedur atraksi dan mengikuti seluruh aturan yang ditetapkan perusahaan/pengelola, menjaga keselamatan diri sendiri maupun wisatawan serta memahami kondisi kawasan atraksi dengan baik.

Ada beberapa konsep yang digunakan untuk menganalisis permasalaham dalam penelitian ini diantaranya; konsep penerapan oleh (Ali, 1995) untuk menganalisis penerapan terdiri atas program yang akan dilaksanakan, kelompok target yang menjadi sasaran dan akan menerima manfaat dari program tersebut dan pelaksana program baik organisasi maupun perorangan yang bertanggungjawab dalam pengelolaan, pelaksanaan dan pengawasan. Program yang dimaksud adalah penerapan aspek K3 dalam prosedur atraksi sliding dan jumping; konsep tentang keselamatan dan kesehatan kerja menurut (Sucipto, 2014) dan (Suma'mur 1981) dalam (Sucipto, 2014) untuk menganalisis upaya yang dilakukan pengelola dalam menjamin keutuhan jasmani maupun rohani tenaga kerja/guide pada khususnya, dan wisatawan pada umumnya, serta menciptakan suasana aman dan tenteram bagi semua stakeholder yang terlibat dalam kegiatan wisata; konsep atraksi wisata menurut (Soekadijo, 1996) untuk menganalisis bentuk dan jenis atraksi yang dimiliki; dan konsep adventure tourism menurut (Cater, 2000) untuk menganalisis kriteria dan karakteristik atraksi wisata yang tergolong dalam adventure tourism. 


\section{METODE}

Sumber data yang digunakan dalam penelitian ini yaitu data primer dan data sekunder. Data primer adalah data dalam bentuk verbal atau kata-kata yang diucapkan secara lisan, gerak-gerik atau perilaku yang dilakukan subjek yang dapat dipercaya, yakni subjek penelitian atau informan yang berkenaan dengan variabel yang diteliti atau data yang diperoleh dari responden secara langsung. Sedangkan data sekunder adalah data yang diperoleh dari teknik pengumpulan data yang menunjang data primer (Arikunto, 2010).

Dalam penelitian ini, data primer diperoleh melalui informan yang telah ditentukan yaitu stakeholder pariwisata di Desa Sambangan diantaranya, ketua kelompok sadar wisata, guide/pemandu wisata, dan wisatawan. Data sekunder diperoleh dari hasil observasi di lapangan serta studi pustaka berupa data monografi desa, foto-foto, penelitian sebelumnya dan lain-lain.

Untuk mendapatkan data-data tersebut, teknik pengumpulan data dilakukan berdasarkan jenis data yang dibutuhkan, apakah data primer atau data sekunder bahkan kedua-duanya dengan tahapan observasi, wawancara mendalam dan studi pustaka.

Data yang diperoleh dalam penelitian ini akan dianalisis secara kualitatif menggunakan teknik deskriptif-kualitatif. Data yang diperoleh dipilah menjadi satuan yang dapat dikelola, disintesis sehingga ditemukan pola, apa yang penting dan apa yang dapat dipelajari untuk selanjutnya diputuskan apa yang dapat diceritakan kepada orang lain. (Bogdan dan Biklen, 1982 dalam Bungin, 2007).

\section{HASIL DAN PEMBAHASAN}

\subsection{Gambaran Umum}

Atraksi sliding dan jumping merupakan maskot utama atraksi wisata di Desa Wisata Sambangan yang dikelola oleh kelompok sadar wisata Tunjung Mekar dimana sebagian besar pengurus didominasi oleh kaum muda-mudi Desa Sambangan. Atraksi ini berlokasi di kawasan Air
Terjun Aling-Aling, disebut sebagai kawasan Air Terjun Aling-Aling karena; pertama, Air Terjun Aling-Aling dengan ketinggian kurang lebih 30 meter merupakan maskot Desa Sambangan dan paling terkenal diantara air terjun lain yang ada di desa ini. Kedua, di sekitar kawasan air terjun tersebut, masih terdapat tiga air terjun lagi yang masih berada dalam satu kawasan dimana lokasinya secara beruntun ke arah utara bawah dengan radius kurang dari 100 meter dari air terjun satu ke air terjun selanjutnya. Sebelah utara Air Terjun Aling-Aling terdapat Air Terjun Kroya atau dalam Bahasa Bali disebut juga Tibuan Kroya (12 meter). Tibuan berarti sebuah pemandian. Tempat ini memang menyerupai sebuah kolam pemandian, sehingga orang-orang lebih lazim menyebutnya dengan nama Tibuan Kroya. Selanjutnya, turun ke bawah utara dengan jarak kurang dari 100 meter, kita akan menjumpai Air Terjun Kembar (10 meter). Dan air terjun terakhir yang terletak paling bawah bernama Air Terjun Pucuk (15 meter).

Atraksi sliding dan jumping dikemas ke dalam paket trekking. Ada tiga jenis paket trekking diantaranya short, medium dan long trekking. Paket trekking yang paling sering dibeli wisatawan adalah short trekking. Dalam paket ini jalur trekking tidak terlalu jauh dan di sini wisatawan dapat melakukan atraksi sliding dan jumping lebih banyak karena kegiatan terfokus di kawasan Air Terjun Aling-Aling yaitu di Air Terjun Kroya, Air Terjun Kembar dan Air Terjun Pucuk.

\subsection{Penerapan Keselamatan Dan Kesehatan Kerja (K3) Pada Atraksi Adventure Tourism Di Kawasan Air Terjun Aling - Aling Sambangan}

Peranan kesehatan dan keselamatan kerja sangat penting untuk menjamin keselamatan dan kesehatan baik jasmani maupun rohani seseorang di tempat bekerja. Tempat bekerja dalam penelitian ini adalah lokasi atraksi sliding dan jumping di kawasan Air Terjun Aling-Aling yakni pada Air Terjun Kroya tempat melakukan sliding, Air Terjun Kembar dan Air Terjun Pucuk tempat atraksi jumping. Penerapan K3 pada atraksi adventure tourism diterapkan pada tiga komponen yang terkait dengan pelaksanaan 
atraksi diantaranya atraksi sliding dan jumping itu sendiri, K3 pada guide, dan wisatawan.

\subsubsection{Penerapan Keselamatan dan Kesehatan Kerja Pada Atraksi Sliding dan Jumping}

Adapun penerapan kesehatan dan keselamatan kerja yang saat ini diterapkan oleh pihak pengelola saat ini masih sederhana sebagai berikut:

1. Peralatan keselamatan yang didapatkan wisatawan pada saat melakukan atraksi adalah life jacket atau jaket pelampung. Wisatawan yang bisa berenang diperbolehkan untuk tidak menggunakan jaket keselamatan, sebaliknya wisatawan yang tidak bisa berenang namun tetap ingin melakukan atraksi tersebut harus menggunakan jaket pelampung.

2. Pengecekan terhadap kondisi kolam di masingmasing air terjun untuk memastikan bahwa tidak terdapat benda-benda asing di dasar kolam sebelum kegiatan atraksi dimulai. Terdapat pula kegiatan gotong royong secara rutin di sekitar air tejun setiap seminggu sekali.

3. Untuk memastikan kondisi air aman, maka salah satu pemandu bertugas sebagai pemantau kondisi air dengan berada di bagian hulu air terjun dan berkomunikasi lewat HT. Dengan alat tersebut ia akan berkomunikasi dengan pemandu yang bertugas menemani wisatawan pada saat itu.

4. Sementara itu, pada bagian hilir kolam sudah ada satu atau dua pemandu lainnya yang bertugas untuk menunggu/menjaga wisatawan saat mereka selesai melakukan atraksi.

5. Atraksi yang akan dilakukan wisatawan pertama kali adalah adalah sliding di Tibuan Kroya. Pemandu akan menanyakan sekali lagi kesiapan wisatawan pada saat berada di lokasi untuk memastikan apakah mereka berani atau tidak untuk meluncur di tibuan tersebut. Wisatawan tidak akan dipaksa apabila mereka tidak sepenuhnya yakin/ragu-ragu.

6. Setelah pemandu memberikan intruksi, maka wisatawan akan dituntun untuk langsung mempraktikkan. Kunci keberhasilan dalam melakukan atraksi ini adalah keberanian dan ketenangan. Jadi, dengan tenang pemandu memberikan saran kepada wisatawan agar mereka tidak panik pada saat meluncur ke bagian bawah kolam.

7. Setelah puas melakukan sliding di Air Terjun Kroya, atraksi selanjutnya yang dilakukan adalah jumping atau melompat di Air Terjun Kembar yakni dari bagian permukaan atas air terjun menuju ke bagian bawah/dasar kolam. Jarak antara air terjun ini sangat berdekatan bahkan kurang dari 50 meter. Sama halnya seperti sebelumnya, sebelum wisatawan melakukan atraksi jumping ini, kesiapan mereka ditanya kembali dan mereka diberikan intruksi melompat yang benar.

8. Setelah diperagakan pertama kali oleh pemandu, kemudian wisatawan mempraktikkan sebagaimana yang telah diintruksikan.

9. Wisatawan boleh melakukan kedua atraksi baik sliding maupun jumping sepuasnya. Apabila wisatawan mengalami cedera kecil, maka pihak pengelola sudah menyediakan kotak P3K pada pos yang tersedia di dekat air terjun tersebut.

Berdasarkan penuturan ketua kelompok sadarwisata (darwis), hampir tidak pernah terjadi kecelakaan berat yang menimpa wisatawan selama mereka melakukan atraksi. Selama wisatawan sudah mengikuti intruksi dari pemandu, dan mendapatkan pengawasan dari pemandu maka pihak pengelola berani memastikan bahwa tidak akan terjadi kecelakaan berat. Apabila hal itu terjadi, maka pihak pengelola sudah siap menanggung risiko yang terjadi yaitu mereka akan menanggung semua biaya pengobatan wisatawan karena mereka telah bekerjasama dengan pihak asuransi. Peristiwa kelam yang pernah terjadi di tahuntahun sebelumnya yaitu kecelakaan yang sampai menimbulkan kematian disebabkan karena peristiwa alam. Oleh karena itu apabila cuaca sedang tidak mendukung atau terjadi hujan deras, maka kegiatan atraksi tidak dilakukan pada hari itu (wawancara, 2016).

\subsubsection{Penerapan K3 pada Guide / Pemandu Wisata}

Tujuan utama dari penerapan Kesehatan dan Keselamatan Kerja (K3) tidak hanya difokuskan pada lokasi maupun atraksi yang dilakukan. Keselamatan kerja yang dimaksudkan 
juga merupakan rangkaian usaha untuk menciptakan suasana kerja yang aman bagi para pemandu yang bekerja atau bertugas untuk mendampingi wisatawan pada saat melakukan atraksi. Para pemandu wisata/guide lokal yang bekerja di kelompok sadar wisata tidak serta merta diterima begitu saja dan boleh bekerja sesuai dengan keinginan mereka sendiri.

Bagi kaum muda yang ingin bergabung dalam kelompok sadar wisata (darwis) Tunjung Mekar harus mengikuti prosedur yang telah ditetapkan. Pertama-tama harus mengikuti trening selama tiga bulan. Dalam kurun waktu tersebut, guide pemula menjalani masa pelatihan/training dengan cara mengikuti pemandu senior pada saat guiding. Jadi mereka akan dilatih dengan cara sharing pengalaman satu sama lain. Secara otodidak mereka belajar bersama-sama di lapangan. Apabila guide pemula ini sudah fasih melakukan atraksi, memiliki kemampuan renang dan mampu berkomunikasi dalam Bahasa Inggris dengan baik, maka pada saat itulah mereka dinyatakan lulus dan boleh mendampingi wisatawan.

Dengan keahlian yang dimiliki tersebut, setiap guide yang sudah dinyatakan lulus atau diijinkan memandu wisatawan harus mampu bertanggung jawab terhadap kesehatan dan keselamatan dirinya sendiri, menciptakan sistem kerja yang aman dan nyaman sehingga wisatawan yang dipandu merasa aman dan terjamin keselamatannya sedari mereka datang sampai mereka meninggalkan daya tarik wisata. Pemandu harus bersikap secara profesional dan mampu memposisikan diri sebagai penyelamat ketika mengalami suatu kesulitan, hambatan bahkan kecelakaan yang tidak diinginkan. Adapun penerapan kesehatan dan keselamatan kerja pada guide sebenarnya tidak berbeda jauh dengan penerapan kesehatan dan keselamatan kerja pada wisatawan (wawancara, 2016).

Peralatan keselamatan yang digunakan selama memandu wisatawan di lapangan adalah sebagai berikut:

1. Life jacket (jaket pelampung)

2. $H T$ untuk berkomunikasi dengan pemandu lain yang bertugas mengawasi kondisi air di bagian hulu air terjun.

3. Kotak P3K
Adapun penerapan kesehatan dan keselamatan kerja pada guide lokal adalah sebagai berikut;

1. Kondisi fisik guide harus dipastikan sehat jasmani rohani sebelum terjun kelapangan.

2. Masing-masing guide membawa life jacket baik untuk diri sendiri dan wisatawan yang dipandu.

3. Membawa alat $H T$ untuk berkomunikasi maupun berkoordinasi dengan guide yang lain.

4. Membawa peralatan P3K untuk pengobatan pertama apabila mengalami cedera atau kecelakaan ringan.

5. Setiap guide yang betugas mendampingi tamu memiliki satu atau lebih rekan guide, dikondisikan dengan jumlah wisatawan yang datang sehingga guide utama yang bertugas bisa meminta bantuan rekan-rekan lainnya apabila menghadapi kesulitan-kesulitan yang tidak dapat diselesaikan sendiri selama berada di lapangan.

6. Setiap guide di kelompok sadar wisata Tunjung Mekar Sambangan sudah terdaftar asuransi sehingga apabila mengalami kecelakaan atau hal-hal yang tidak diinginkan, biaya pengobatan sepenuhnya ditanggung oleh pihak asuransi.

\subsubsection{Penerapan K3 pada wisatawan}

Keselamatan wisatawan dalam berwisata adalah salah satu bentuk kewajiban dan tanggung jawab pihak pengelola suatu destinasi wisata. Ini juga merupakan salah satu tolak ukur suatu destinasi wisata layak atau tidak untuk dikunjungi khususnya menyangkut aspek keamanan wisatawan. Keselamatan wisatawan adalah hal yang sangat penting dan juga bentuk kepuasaan atas pelayanan yang diberikan. Oleh karena itu, pihak pengelola harus menjadikan hal ini sebagai prioritas utama untuk menjaga citra destinasi di mata wisatawan dan juga adanya trust atau kepercayaan terhadap produk yang ditawarkan dalam hal ini yang dimaksud adalah atraksi sliding dan jumping. Peralatan keselamatan yang didapatkan wisatawan selama melakukan atraksi adalah life jacket / jaket pelampung. 
Berikut di bawah ini bentuk penerapan kesehatan dan keselamatan kerja pada wisatawan:

1. Wisatawan akan diberikan intruksi dari pemandu wisata sebelum melakukan atraksi wisata. Masing-masing wisatawan mendapatkan life jacket, bagi yang tidak bisa berenang diwajibkan menggunakan agar tetap dalam posisi terapung. Sementara bagi wisatawan yang bisa berenang diperbolehkan untuk tidak menggunakan jaket pelampung.

2. Setelah menggunakan life jacket, wisatawan dituntun ke bagian hulu air terjun oleh pemandu. Sebelum terjun, pemandu mendemonstrasikan langkah-langkah untuk melakukan masingmasing atraksi dengan benar.

3. Pada saat wisatawan meluncur maupun melompat ke bagian dasar kolam, beberapa pemandu yang lain sudah siap menunggu di bagian pinggir kolam untuk menjemput wisatawan dan mengantar ke pos peristirahatan.

4. Apabila wisatawan mengalami cedera, kotak P3K sudah tersedia dan mereka boleh beristirahat di pos peristirahatan yang terletak di antara Tibuan Kroya dan Tibuan Kembar.

5. Wisatawan yang mengalami cedera atau kecelakaan yang cukup parah akan dibawa ke rumah sakit dan biaya pengobatan sepenuhnya ditanggung oleh pihak asuransi karena biaya pembelian paket trekking yang dibayarkan sudah termasuk biaya asuransi (observasi, 2016).

\section{SIMPULAN DAN SARAN \\ 5.1 Simpulan}

Atraksi wisata sliding dan jumping yang ada di Desa Wisata Sambangan tergolong ke dalam kegiatan adventure tourism atau kegiatan pariwisata yang berhubungan dengan aktivitas petualangan karena dalam pelaksanaannya terdapat unsur tantangan/uji nyali, menguras emosi, adanya resiko yang harus diantisipasi, dan tentunya ada pengalaman baru yang diperoleh dari aktivitas adventure tourism tersebut. Petualangan ini melibatkan usaha maupun komitmen orang yang bersangkutan, selalu ada persiapan mental dan fisik serta pelatihan/pengarahan bila diperlukan.

Penerapan kesehatan dan keselamatan kerja (K3) pada atraksi sliding dan jumping di kawasan Air Terjun Aling-Aling sudah baik, namun masih bersifat seadanya. Hal tersebut disebabkan oleh keterbatasan dana dan kurangnya pemahaman di bidang kesehatan serta tidak ada sumber daya manusia yang berkompeten dalam bidang tersebut. Sarana keselamatan utama pada saat melakukan atraksi adalah life jacket baik bagi guide maupun wisatawan dan HT yang digunakan untuk controlling. Selain itu setiap guide dituntut memiliki kemampuan renang yang baik sehingga dapat mengantisipasi atau memberikan pertolongan kepada wisatawan tatkala mendapatkan kesulitan selama berada di air. Pada pos peristirahatan terdapat pula kotak P3K untuk memberikan pertolongan pertama pada cedera atau kecelakaan yang bersifat ringan. Apabila terjadi kecelakaan skala besar, maka pihak pengelola akan membawa korban ke rumah sakit dan biaya pengobatan ditanggung pihak asuransi karena paket wisata yang dijual sudah include biaya asuransi.

\subsection{Saran}

\subsubsection{Saran Kepada Pengelola}

Berikut beberapa saran yang penulis ajukan kepada pihak pengelola Desa Wisata Sambangan dalam hal ini Kelompok Sadar Wisata Tunjung Mekar, yaitu;

1. Untuk meningkatkan aspek kesehatan dan keselamatan pada atraksi sliding dan jumping terlebih juga bagi keselamatan Guide dan wisatawan, pihak pengelola harus melakukan riset kesehatan atau berkonsultasi dengan pakar kesehatan terkait dengan resiko atau efek samping yang dialami tubuh setelah melakukan atraksi sliding dan jumping.

2. Selama ini pihak pengelola belum menentukan syarat-syarat yang memenuhi kriteria wisatawan untuk melakukan atraksi sliding dan jumping, misalnya syarat minimal umur, berat badan, riwayat kesehatan sebelumnya dan lainlain. Ini sebenarnya sangat penting diketahui dan diterapkan untuk mengantisipasi cedera atau trauma yang berkaitan dengan aspek kesehatan.

3. Sarana keselamatan harus lebih ditingkatkan, dimana selain life jacket diperlukan juga helm untuk melindungi kepala dari benturan, 
4. pelindung siku pada lengan dan kaki serta yang lain-lain. Sehingga pihak pengelola juga perlu untuk mencari referensi tentang jenis peralatan safety yang digunakan dalam atraksi tersebut.

5. Pihak pengelola seharusnya membuat ramburambu keselamatan di sepanjang jalur trekking dan di sekitar kawasan air terjun tempat atraksi dilakukan.

6. Pengelola Kelompok Sadar Wisata Tunjung Mekar Desa Sambangan hapir 95 persen didominasi oleh kaum pria, oleh karena itu diperlukan juga adanya kesetaraan gender dalam hal ini peran kaum perempuan harus diperhatikan lagi.

\subsubsection{Saran Kepada Pemerintah}

Pemerintah Kabupaten Buleleng dalam hal ini Dinas Kebudayaan dan Pariwisisata seharusnya memberikan perhatian khusus kepada desa-desa wisata yang sedang berkembang saat ini. Bantuan maupun dukungan baik secara material dan nonmaterial sangat diperlukan untuk kemajuan dan peningkatan kualitas manajemen pengelolaan desa wisata.

1. Peralatan dengan teknologi yang canggih juga diperlukan untuk mendeteksi adanya hal-hal yang berbahaya misalnya alat pendeteksi banjir.

2. Di setiap hilir air terjun tempat melakukan atraksi, sebaiknya dibangun semacam tanggul untuk menahan orang yang hanyut apabila tidak sengaja terbawa arus. Hal ini untuk mengantisipasi apabil terjadi hal-hal tak terduga.

\section{DAFTAR PUSTAKA}

Anonim. Undang-Undang Kepariwisataan No.10 tahun 2009

Balipost.com. Polisi Tewas di Air Terjun Aling - Aling, http://balipost.com/read/headline/2014/09/28 /22251/polisi-tewas-tenggelam-di-air-terjunaling-aling.html (diakses 14 April 2015)

Bungin, 2007. Penelitian Kualitatif. Jakarta: PRENADA MEDIA GROUP

Swarbrooke, John. 2003. Adventure Tourism The New Frontier. Great Britain : Elsevier Science

Dalem, Raka. 2009. Potensi, Prospek dan Penyusunan Program dalam Pengembangan Ekowisata di Desa Sambangan, Kecamatan Sukasada, Kabupaten Buleleng (makalah ceramah).
Lokakarya Ekowisata di Desa Sambangan pada tanggal 15 April 2009: tidak diterbitkan.

Kusmayadi, Ir., dan Ir. Endar Sugiarto, MM. 2000. Metodologi Penelitian Dalam Bidang Kepariwisataan. Jakarta : PT Gramedia Pustaka Utama.

Paramitha, Fernia. 2012. Sarana Keselamatan Pengunjung Wisata Pantai (Studi Kasus Pantai Indah Ancol dan Pantai Jakat Bengkulu). Skripsi Sarjana pada Universitas Indonesia: tidak diterbitkan.

Pitana, I Gde dan I Ketut Surya Diarta. 2009. Pengantar Ilmu Pariwisata. Yogyakarta : Penerbit Andi.

Ramli, Soehatman. 2010. Sistem Manajemen Keselamatan dan Kesehatan Kerja OHSAS 18001. Jakarta : PT. Dian Rakyat.

Sucipto, Cecep Dani, 2014. Keselamatan dan Kesehatan Kerja. Yogyakarta : Gosyen Publishing

Sugiono, Prof. Dr. 2014. Cetakan ke-14. Metode Penelitian Kuantitatif, Kualitatif dan R\&D. Bandung : ALFABETA,CV.

Sultengpost, Keselamatan di Lokasi Wisata, http://sultengpost.com/?p=5466 (diakses 16 April 2015).

Pitana, I Gde dan I Ketut Surya Diarta. 2009. Pengantar Ilmu Pariwisata. Yogyakarta : Penerbit Andi.

Ramli, Soehatman. 2010. Sistem Manajemen Keselamatan dan Kesehatan Kerja OHSAS 18001. Jakarta : PT. Dian Rakyat.

Sucipto, Cecep Dani, 2014. Keselamatan dan Kesehatan Kerja. Yogyakarta : Gosyen Publishing

Sugiono, Prof. Dr. 2014. Cetakan ke-14. Metode Penelitian Kuantitatif, Kualitatif dan R\&D. Bandung : ALFABETA,CV.

Sultengpost, Keselamatan di Lokasi Wisata, http://sultengpost.com/?p=5466 (diakses 16 April 2015).

Tribun Bali. Coba Selamatkan Wisatawan Hanyut, Tour Gude Ini Hilang dan Belum Ditemukan,http://bali.tribunnews.com/2015/04 /12/coba-selamtkan-wisatawan-hanyut-tourGuide-ini-hilang-dan-belum-ditemukan (diakses 14 April 2015)

WTO, 2003. Tuntunan Keselamatan dan Keamanan Wisatawan. Jakarta : PT. Pradnya Paramitha. 